\title{
Marketing Strategy and the Potency of Inclusive Education Throughout Surakarta Ex-Residency
}

\author{
Widodo Muktiyo ${ }^{1 凶}$ \\ ${ }^{1}$ Social and Political Sciences Faculty, Surakarta Sebelas Maret University
}

http://dx.doi.org/10.15294/komunitas.v8i1.5211

Received : 29 February 2016; Accepted: 14 March 2016; Published: 31 March 2016

\begin{abstract}
This research studied marketing strategy and promotion communication in child growth and development clinic as the pillar of inclusive education. Particularly, the objectives of current research were to map the market of child growth and development clinic throughout Surakarta Ex-residency, to recommend the marketing strategy in child growth and development clinic, to analyze the external factors affecting the child growth and development clinic sustainability, and to recommend differentiation and promotion communication of child growth and development clinic. This study was taken place in Surakarta ex-residency. The type of research used was mixed-method. The strategy employed was quantitative descriptive and grounded research. The result of research showed that potency of inclusive education market in Surakarta ex-residency was sufficiently high, as could be seen from the highly potential development of child growth and development clinic. The result of research also showed the marketing strategy of growth and development clinic and market share in each area of Surakarta ex-residency (Solo, Wonogiri, Sukoharjo, Boyolali, Klaten, Sragen): (a) affordable price, (b) product variation adjusted with the most case: learning retarded, mental retarded, quadriplegic, deaf and multiple disabled, (c) safe, kids-friendly physical environment and adequate facility, (d) service hour and time clarity for each type of service, (e) experience medical personnel, (f) promotion through a variety of media types, (g) cooperation and network system.
\end{abstract}

Keywords: child growth development clinic; inclusive school; promotion communication

\section{INTRODUCTION}

Inclusive education is an education organization system giving all of disabled students, students with potential intelligence and gifted students an opportunity of attending education or learning in education environment along with common students (Permendiknas [National Education Minister's Regulation No.70 of 2009). Resent studies about inclusive education (Ainscow 2005; De Boer, Pijl, \& Minnaert 2011; Lindsay 2007; Slee 2001; Lindsay 2003; Wilczenski 1992; Pivik, McComas \& Laflamme 2002) underlines the importance of developing strategies to promote inclusive education. This study gives an addition by exploring how a residency in Indonesia develops such a strategy.
Indonesian Government begins to direct development strategy focusing on mainly the sustainability and inclusiveness. PPN/Bapenas Ministry's data presented in INFID conference In Jakarta (2013) indicated that inclusive development agenda has belonged to the government's commitment included into RPJMN 2010-2014 (National Medium-Term Development Plan of 20102014). Furthermore, inclusive development should focus on the pillars of inclusive development, one of which is social inclusion including health and education access, basic infrastructure, and gender mainstreaming.

Education and Culture Ministry (Kemendikbud) aims at inclusive education development in Solo City. It is because, educa-

(c) 2016 Semarang State University. All rights reserved p-ISSN 2086 - 5465 | e-ISSN 2460-7320

Address: Ir. Sutami Street No. 36A, Central Java Indonesia 57126

Email : muktiyo@yahoo.com

Telp : +6285725117255

UNNDS JUURNALS


tion institution in Solo had applied inclusive model to the students with special need, despite further development needed. Considering the result of research, the factors affecting successful or failed implementation of inclusive education policy are communication, resource, disposition and bureaucratic structure. For that reason, support is required from many parties to the achievement of inclusive development (Prastiyono 2013).

Inclusive school is a metamorphosis of increasingly modern and global human culture, that every man is equal, has equal right, and opportunity to develop and to get education for the sake of his better life sustainability (Ainscow 2005; Lindsay 2007; Wilczenski 1992; Pivik, McComas \& Laflamme 2002). Regardless color, race, religion and genetic, everyone is entitled to be equal. Inclusive school is one of answer that education is not discriminative, that everyone deserves to get it. Inclusive education is one attempt of removing the constraints among the students and of improving the opportunity of obtaining education among everybody including the students with special needs (Asiyah 2012; De Boer, Pijl and Minnaert 2011).

WHO (2007) stated that the number of children with special needs (thereafter called $\mathrm{ABK}$ ) in Indonesia is about $7 \%$ of total o-18 year children or about $6,230,000$ and this number will keep increasing. The Central Statistical Bureau's Census data of 2003 shows the number of disabled people in Indonesia about $0.7 \%(1,480,000)$ of total population $(211,428,572$ people). Out of this number, $24.45 \%(361,860)$ of $0-18$ year children and $21.42 \%(317,016)$ children are school age children with special needs (518 years old). In 2009, the number of ABK attending school is $85,645: 70,501$ in school for children with special needs (thereafter called SLB) and 15,144 in inclusive school. It means that many ABKs are still under parent's or family's supervision or even have not gotten access yet to duly healthcare.

Recently, the society has started to be aware of paying special attention to children's physical, mental/psychological and social growth and development. However, despite high awareness among parents, they still refer to maternal and child hospital with limited skilled personnel and facility. For that reason, establishing a complete growth and development center has been a requirement (Slee 2001; Lindsay 2003).

Surakarta City has declared itself as inclusive city; thereby a more complete service is required, including health service. Based on data of BP-Diksus (Special Education Development Office), the number of children with special needs in Surakarta exresidency is 10,000. Meanwhile, the investigation of secondary data shows that there are 24 clinics of child growth and development, including public or private hospital. It indicates that there is a gap between the number of children with special needs and the number of child growth and development service clinic. On the one hand, it of course benefits the consumers because there are more alternative choice of place for the parents to have their children's growth and development controlled, but on the other hand, it will generate threat to the clinic organizers because they should deal with tight competition for the existing consumer number.

This study has general objective, to map the market of inclusive education, and particularly objectives: (1) to map the market of child growth and development clinic throughout Surakarta ex-residency, (2) to recommend the marketing strategy of child growth and development clinic, (3) to analyze the external factors affecting the sustainability of child growth and development clinic and (4) to recommend differentiation and promotion communication of child growth and development clinic.

\section{RESEARCH METHODS}

This study was a research on marketing strategy and promotion communication of child growth and development clinics throughout Surakarta ex-residency. The research method used in this study was mixed-method strategy with dominant-less dominant strategy, dominant qualitative and less dominant quantitative. The strategy intended in 
quantitative research was descriptive quantitative one. The quantitative data source was obtained through distributing questionnaire to parents of children with special needs to find out the consumer behavior and market potential of child growth and development clinic plan thereby formulating marketing strategy. Questionnaire is distributed as well to the general public, to find out the external aspect, particularly social-cultural aspect of clinic establishment. Meanwhile, the strategy in qualitative research was grounded research. Qualitative data source was obtained through interview and observation on inclusion-related institution/foundation/community. In addition, the data was obtained from growthdevelopment clinic throughout ex-residency through direct interview or go shopping constituting a technique of collecting marketing research data.

\section{RESULTS AND DISCUSSION}

\section{Community's Perspective on Inclusive- ness}

As the gate to introduce growth-development clinic to the public, it is very important to find out how the community's knowledge and perspective is on ABK (Anak Berkebutuhan Khusus). Then, some other factors should be taken into account as well, including management, handling, right to education and government's attention to ABK in the form of inclusion policy. Recognizing such the condition will help determine the appropriate-target and effective marketing strategy.

Hamudy (2015) in Journal of Community volume 7 explained Surakarta City's struggle to be Kids-friendly City (Kota Layak Anak thereafter called KLA). As the city launched as a Kids-friendly City (KLA), Surakarta city has had some child-friendly public health centers (puskesmas ramah anak). Those puskesmas are equipped with child-specific waiting room completed with playground. In addition, the services for children such as Nutrition Park, breastfeeding corner, pediatrician, child-counseling service and service for violence victim children, and many other programs. It is not surprising that the PPPA ministry scores 713 to total value existing in the 31 indicators of KLA the Surakarta City has met.

The result of data collection shows that the Soloraya people have known ABK term with $71 \%$ of total respondents. It suggests good indication that the community has absorbed much information.

Knowledge on ABK term

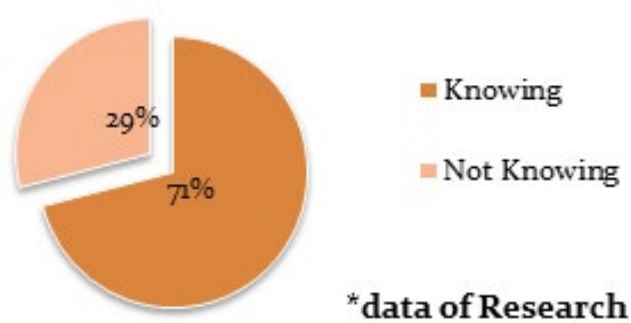

Chart 1. Knowledge an ABK term

\section{Information Source of Knowledge on ABK}

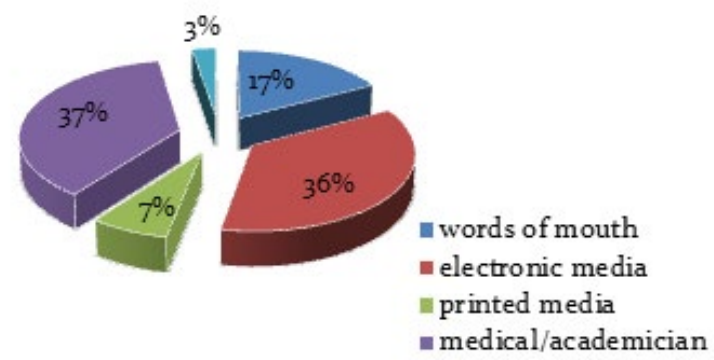

'data of Research School (2015)

Chart 2. Information source of knowledge on $\mathrm{ABK}$

The knowledge on $\mathrm{ABK}$ gives adequate evidence that the information of $\mathrm{ABK}$ is socialized adequately to the society; it can be seen from the presence of some information source used by the society in accessing knowledge on $A B K$. The information source of knowledge on ABK largely derives from academician/medical personnel of $37 \%$. It indicates that the role of academician and medical personnel is sufficiently high in giving information and education concerning child with special needs. In addition, in this digital era, it confirms that electronic media such as TV, radio, handphone, laptop/com- 
puter and more rapidly internet development provides information and education more effectively to the society.

Knowledge on ABK is also affected by the presence of $\mathrm{ABK}$ around their residence neighborhood. The result of field observation shows that the community knows ABK better when there is ABK around their residence. In addition, the presence of $\mathrm{ABK}$ becomes a rationale of child growth-development clinic availability in the concerned location. Data collection shows that the proportion of ABK presence in Surakarta exresidency is $47 \%$, and $53 \%$ of respondents state that there is no ABK found in their neighborhood. Knowledge on ABK derives from words of mouth and some myths of ABK. The community has some strong belief that ABK is a consequence of their parents' past bad behavior during their gestation and so forth. The data found shows that some members $(40 \%)$ of community know the myth and most $(60 \%)$ of them do not know or do not believe in the myth developing but they believe that $\mathrm{ABK}$ condition is due to medical factor.

Education for $A B K$ is the aspect to be met because somehow ABK remains to have right to attending education. The result of investigation within the society shows that $24 \%$ of ABK have not attended any school yet. Meanwhile, the community's preference concerning the most appropriate type of school for ABK is Special School (thereafter called SLB). Considering the result of research, it can be found that most members $(63 \%)$ of society argue that ABK should be enrolled in SLB rather than in other school because they are considered as incapable of adapting to their other friends when they are enrolled in regular school, and because of limited knowledge on inclusive school. However, about $30 \%$ of community members prefer inclusive school because if ABKs are put in SLB continuously, they would not develop. They argue that the presence of inclusive school organized widely has become an alternative for $\mathrm{ABK}$ to acquire better education.

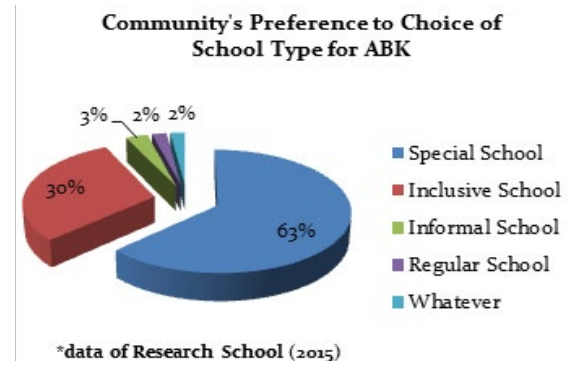

Chart 3. Community's preference to choise of school type for ABK

Most members of community in Surakarta ex-residency area have not known yet the inclusive school. It is indicated with the percentage gain of $66 \%$ and only few (34\%) members of community know about inclusive school. The members of community's poor knowledge on inclusive school can be seen from the limited knowledge on inclusion itself. Meanwhile, inclusion policy has been implemented in some areas, but it has not been known widely by the society. From the data collected, it can be seen that most (69\%) respondents do not know inclusive policy and even they newly hear that term, and only few (31\%) have known inclusion policy. Only those coming from certain profession class, for example those working in health sector, teacher often pertaining to inclusive school and some from government profession are familiar with inclusion. Although only few know inclusion policy, but members of community welcome such the policy optimistically. It can be seen from the data gain mentioning that $68 \%$ of respondents state their agreement and $66.7 \%$ state their optimism with the implementation of inclusion policy.

In addition to formal school, the presence of growth-development clinic becomes an alternative to provide education and to deal with ABK, despite poor knowledge on child growth-development clinic among the members of community.

The proportion of community members knowing the child growth-development clinic is $37 \%$ and that of those knowing it is $63 \%$. It can be stated that the presence of growth-development clinic within community still needs socialization. Although knowledge on child growth-development clinic 
Table 1. Community's knowledge on inclusive school, growth-development clinic, and inclusion policy

\begin{tabular}{lccc}
\hline & $\begin{array}{c}\text { Knowledge on inclu- } \\
\text { sive school }\end{array}$ & $\begin{array}{c}\text { Knowledge on growth- } \\
\text { development clinic }\end{array}$ & $\begin{array}{c}\text { Knowledge on } \\
\text { inclusion policy }\end{array}$ \\
\hline Knowing & $34 \%$ & $57 \%$ & $31 \%$ \\
Not Knowing & $66 \%$ & $43 \%$ & $69 \%$ \\
Necessary & $68 \%$ & $91 \%$ & $68 \%$ \\
Unnecessary & $32 \%$ & $9 \%$ & $32 \%$ \\
\hline
\end{tabular}

\section{*data of research school (2015)}

is still small but the community still needs the presence of child growth-development clinic. It suggests the presence of positive response to the presence of child growthdevelopment clinic in their neighborhood. Such the positive response is confirmed by the community's interest in information around child's growth-development clinic $(69 \%)$ so that clinic accessibility is affordable to the community because they recognize it enthusiastically.

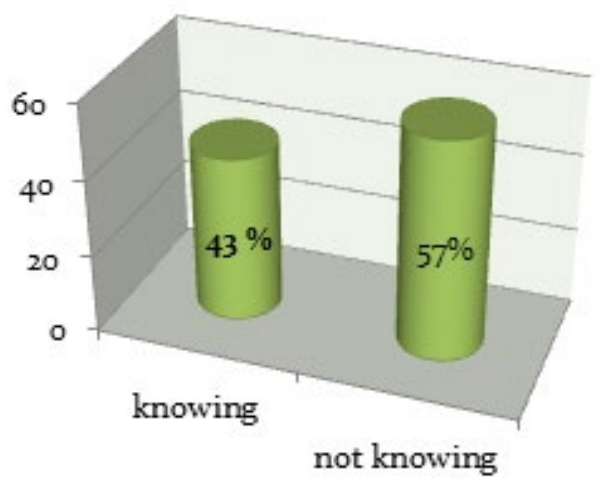

$\square$ Knowledge on child growth-development clinic

*data of Research School (2015)

Chart 4. Knowledge on child growth-development clinic

Parents play a very big role in determining education decision and in dealing with $A B K$ including in the term of accessing the child growth-development clinic. Most (52\%) parents state that it is important to deliver their child to growth-development clinic and some other (31\%) state that it is very important to do so.

The comparison of findings concerning the members of community's knowledge and their attitude to the knowledge in the field can be seen in the table 1.

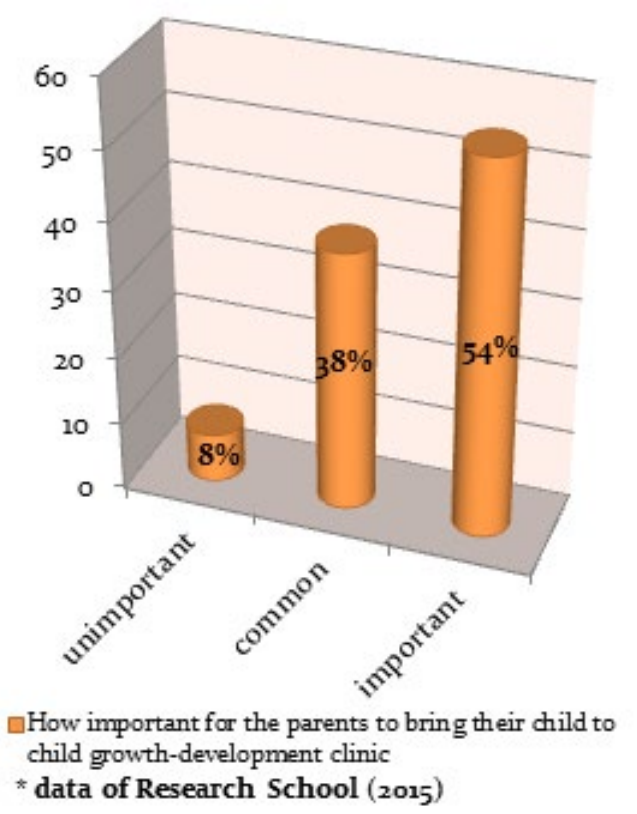

Chart 5. How important for the parents to bring their child to child growth-development clinic

Considering the fact, it can be concluded that the community's knowledge on inclusive school and inclusive policy is proportional inversely to their positive attitude. Meanwhile more positive matter can be seen from knowledge on growth-development clinic matching their optimistic attitude. It becomes big opportunity for the child growth-development clinic to enter into the society. The strategy to be constructed is to build opinion within the society to confirm the care about ABK through socialization, education (illumination), or seminar to confirm the importance of Child GrowthDevelopment Clinic presence, and how to deal with it.

\section{Market Share}


Table 2. The data of some clinics in Solo Raya area and the mean number of ABK catered

\begin{tabular}{lcc}
\hline \multicolumn{1}{c}{ Clinic Name } & $\begin{array}{c}\text { mean number of ABK } \\
\text { catered to per day }\end{array}$ & Market Share \\
\hline PNTC & 80 & $26,75 \%$ \\
YPAC & 60 & $20,06 \%$ \\
PLA & 30 & $10,03 \%$ \\
RSJD Wedi RM. Soedjarwadi & 30 & $10,03 \%$ \\
Cerdas Ceria Child Clinic & 24 & $8,03 \%$ \\
Torison Autistic Child Building Foun- & & \\
dation & 17 & $5,68 \%$ \\
Mutiara Center & 15 & $5,02 \%$ \\
YAMET (Klaten) & 15 & $5,02 \%$ \\
Amanah Therapeutic Center & 5 & $1,67 \%$ \\
Tiara Kidz & 5 & $1,67 \%$ \\
PUSPALENTA & 3 & $1,03 \%$ \\
Others & 15 & $5,02 \%$ \\
\hline Total & 299 & $\mathbf{1 0 0} \%$ \\
\hline Source: Dataf $\%$
\end{tabular}

Source: Data of Research School (2015)

Market share is the one that can be mastered by company compared with the industry's total sale (total sale of similar companies). Thus, it can be stated that market share is the proportion of company's ability against total sale of all competitors, including the company's own sale.

Market share mastered by company in this research is explained through the mean number of ABK catered to by each of clinics per day. The data of some clinics in Solo Raya area and the mean number of ABK catered to is illustrated in Table 2.

Considering the data above, the market leader of child growth-development clinics in Soloraya is PNTC with the mean number of $A B K$ catered to per day of 80 children or $26.75 \%$ of total ABK number accessing the clinics. In the second largest position of market leader, there is YPAC with

\section{MARKET SHARE}

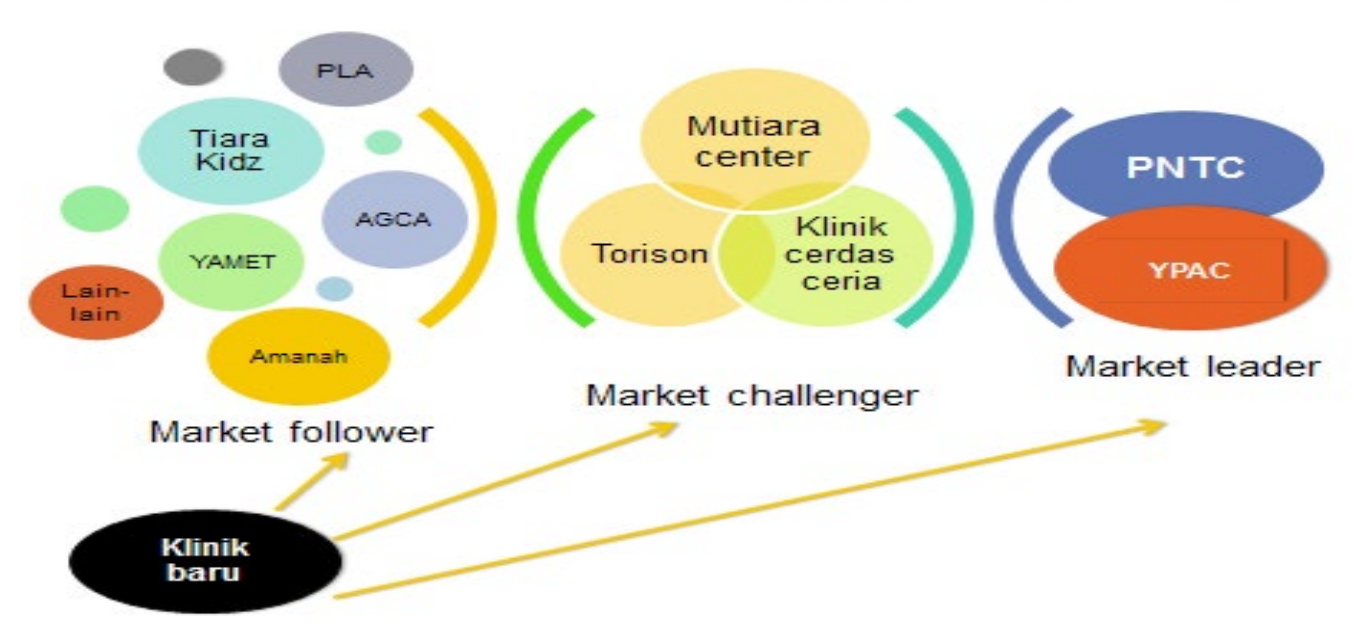

Figure 1. Marker share 
$20.06 \%$, followed by PLA with $10.03 \%$ parallel to Child Growth-Development Clinic of RSJD Wedi Klaten. The clinics with market share less than $10 \%$ are Cerdas Ceria Child Clinic (8.03\%), Torison Autistic Child Building Foundation (5.68\%), Mutiara Center and YAMET Klaten (5.02\%), Tiara Kidz and Amanah Therapeutic Center (1.67\%), Puspalenta $(5 \%)$ and etc $(5 \%)$.

Growth-development clinic to be established can improve market share by following the advantages of competitor making the consumers interested in accessing the clinic without abandoning the competitive advantage the child growth-development clinic. In addition, about 8069 ABKs have not accessed growth-development clinic leading to the clinic's opportunity of improving its market share. Some parents of $A B K$ move from one clinic to another with various considerations resulting in an opportunity of attracting the consumers with the best facility and service provided. For that reason, parents of $A B K$ having not accessed the ABK clinic should be educated through promotion made and complete facility and first-rate service should be provided in order to be competitive with other clinics.

\section{Marketing Strategy and Promotion Communication}

Marketing strategy, according Armstrong and Kotler (1997, p.37), is "The marketing logic by which the bussiness unit hopes to achieve its marketing objective". Meanwhile marketing communication is the management process through dialogue with audiences in an organization in which the organization should develop, present, and evaluate a series of messages to the identified group of stakeholders to achieve it (Muktiyo (ed) 2013, p.7).

In this case, marketing communication strategy has three objectives: to make the consumers knowing a product's existence, what for the product is created, and for whom (awareness), to generate a desire to have or to obtain product (interest), and to maintain the customer loyalty to prevent the consumers from switching to other product (Kusumastuti in Muktiyo (ed), 2015).
Therefore, an appropriate strategy is needed to achieve those objectives.

The result of analysis has implication to marketing mix strategy. Marketing strategy includes 7 elements $(7 \mathrm{P})$ : product, price, place, promotion, people, process, and physical evidence.

\section{Product}

Supporting facility and equipment is adjusted with market potential. The case variation of children with special needs with largest proportion in Surakarta ex-Residency includes: learning retarded, mental retarded, quadriplegic, deaf, and multiple disabled. For that reason, the therapy appropriate to case variation becomes superior product with existing market potency. In addition for non-ABK service, it is recommended to provide early pregnant women detection, baby clinic, and pre-school (school preparation for 2-4 year children) services.

\section{Price}

There are some consumers feeling not satisfied with the price offered by the preexisting growth-development clinics. The consumers feel that the price offered is not compensated with their children's growthdevelopment progress. In addition, considering the result of research, some consumers belong to switcher buyer category, those highly affected by price factor. For that reason, the child growth-development clinic should keep maintaining its service quality in 2 alternative ways. The first one is affordable price consistent with consumers' purchasing power and no tendency to increase continuously. This way is very risky because of the large cost of child growth-development facility. To deal with loss, the solution is to cooperate with donor institutions, like what has been done by YPAC, PNTC, Mitra Ananda, and etc. The second is if they want to raise the price, this rise should be compensated with the better service quality. However, considering the market potency, some of which is still middle-lower class, the consumers cannot afford it. For that reason, the installment system can be enacted just like what PNTC has done. In addition, they 
can cooperate with government through BPJS (Social Insurance Organizing Agency) and Jamkesmas thereby providing discount for certain service. It will attract more consumers to access the clinic with enacted provision and condition.

\section{Place}

In this research, it can be found that one factor affecting the consumers in accessing the clinic is the proximate distance of their house to clinic. There are two alternative things to be done. Firstly, child growthdevelopment can use ball picking system and cooperate with institution/community caring about ABK in local area. Secondly, clinic can establish communities in local areas using Community Based Management (CBM), just like inclusive studio. The most important thing in this method is public participation. For that reasons, network management should be employed in its implementation. In this way, the middle-lower consumer can be embraced as well.

\section{Promotion}

Based the result of research, many parents have not known yet the growth-development clinic. For that reason, new clinic should make socialization not only through school and seminar, but also through other public spaces, recalling that many children have not been enrolled at school. The socialization can be done using booklet as well because so far existing clinics use brochure only. Thus information delivered to consumer is limited and not detailed.

In addition, clinic management can offer membership to consumers to make them more loyal. This membership offer is considered as very profitable for those belonging to committed buyer type. Another strategy that can be taken is promotion strategy through internet. Considering emarketer's data, internet users are 83.7 millions in number in 2014 and are projected to increase continuously in the following year. Majority users are youngsters so that it can be expected that this media is effective enough as promotion media.

\section{People}

Considering the result of research, physician/medical personnel belong to main reason of clinic access. Clinic and the similar become famous even preferred by the consumers because the reason of physician/therapist/psychologist practicing in the clinic. Therefore, clinic management should recruit the more experienced medical personnel particularly concerning the child growth and development. In addition, the practicing medical personnel should have expert certification.

\section{Process}

The management of child growth-development clinic should pay attention to existing process in any business activities, one of which is time clarity of any service type. The timing of each service should be clear thereby facilitating the consumers adjust time to service type intended, just like in cerdas ceria clinic. But in practice, consumers/customers usually make appointment first with physician/therapist/psychologist.

In addition, service hour should be made everyday from morning to evening. Similarly, cerdas ceria clinic opens everyday from 08.00 a.m.-o8.oo p.m. It is necessary to adjust with the consumers' different preoccupation.

\section{Physical Evidence}

The primary interior concept in the child growth-development service building is safety and kinds friendly. Then, there should be comfortable waiting room for parents or escort. In addition, factor affecting the access to clinic for middle-lower class requires the parking area to be available. The clinic management should consider parking area for consumers, for either four-wheel or twowheel vehicle. It is intended to prevent the accumulation of consumer vehicles from occurring and to anticipate the grievance likely coming from the consumers.

\section{CONCLUSION}

The result of research shows that there is a big opportunity for the child growthdevelopment clinic to enter into Surakarta 
ex-residency. The strategy to be established was to build public opinion to confirm the importance of child growth-development clinic presence through socialization, education, or seminar. In addition, there should be a strategy referring to ${ }_{7}$ Ps marketing mix: (a) affordable price, (b) varying product adjusted with the most case including learning retarded, mental retarded, quadriplegic, deaf, and multiple disabled, (c) safety, kids friendly physical evidence, and adequate facility, (d) service hour and time clarity for each type of service, (e) experienced medical personnel, (f) promotion through a variety of media types, and (9) cooperation and system network.

\section{ACKNOWLEDGEMENT}

With the completion of this study the author would like to thank the whole team which has helped the process of implementation as well as to Foundation Council of Education Al-Firdaus who gave the full funding for this research.

\section{REFERENCES}

Ainscow, M., 2005. Developing inclusive education systems: what are the levers for change?. Journal of educational change, 6(2), pp.109-124.

Asiyah, D., 2012. Dampak Pola Pembelajaran Sekolah Inklusi terhadap Anak Berkebutuhan Khusus (Studi Kasus Sekolah Dasar Sada Ibu di Cirebon). Institut Agama Islam Negeri (IAIN) Syeh Nurjati, Cirebon.

Babbie, E., 2006. Menerapkan Metode Penelitian Survey untuk Ilmu-Ilmu Sosial. Palmall, Yogyakarta.

Charles W. L,, Joseph F. H., Carl D. 2001. Pemasaran Edisi Pertama.Salemba Empat, Jakarta

Cravens, W.D. 1996. Pemasaran Strategis Edisi IV. Erlangga, Jakarta.

De Boer, A., Pijl, S. J., \& Minnaert, A. 2011. Regular primary schoolteachers' attitudes towards inclusive education: A review of the literature. International journal of inclusive education, 15(3), pp. 331-353
Hamudy, M.I.A., 2015. Efforts to Promote Surakarta and Makassar as Children Friendly Towns. Jurnal Komunitas. 7(1).

http://www.bpdiksus.org, diakses tanggal 1 Februari 2015.

Kartajaya, H., 2005. Positioning, Differentiation and Brand. Gramedia Pustaka Utama, Jakarta.

Kotler, P. \& Gary, A., 1997. Prinsip-prinsip Pemasaran Jilid I. Erlangga, Jakarta.

Kotler, P. dan K.L. Keller., 2006. $12^{\text {th }}$ edition Marketing Management. Prentice Hall Inc, New Jersey.

Lindsay, G., 2003. Inclusive education: A critical perspective. British Journal of Special Education, 30(1), pp. 3-12.

Lindsay, G., 2007. Educational psychology and the effectiveness of inclusive education/mainstreaming. British Journal of Educational Psychology, 77(1), pp. 1-24.

Muktiyo, W., (ed). 2013. Manajemen Komunikasi Promosi dan Pemasaran. Pulau Lampuan, Surakarta.

Muktiyo, W., (ed). 2015. Dinamika Komunikasi Pemasaran On Line dan Off Line. Surakarta: UNS Press.

Pivik, J., McComas, J., \& Laflamme, M. 2002. Barriers and facilitators to inclusive education. Exceptional children, 69(1), pp. 97-107.

Prastiyono. 2013. Implementasi Kebijakan Pendidikan Inklusif (Studi di Sekolah Galuh Handayani Surabaya. Jurnal Administrasi Publik.

Santoso, S., 2001. Riset Pemasaran Konsep dan Aplikasi. Elex Media Komputindo, Jakarta.

Slee, R., 2001. Social justice and the changing directions in educational research: The case of inclusive education. International journal of inclusive education, 5(2-3), pp. 167-177.

Stanton, W.J., 1984. Fundamentals Of Marketing. Sevent Edition. McGraw Hill,inc. Alih bahasa : Drs Yohames Lamarto. 1994.Prinsip Pemasaran.Edisi Ketujuh. Erlangga, Jakarta.

Subagyo, A., 2007. Studi Kelayakan. PT Elex Media Komputindo, Jakarta.

Sunyoto, D., 2014. Studi Kelayakan Bisnis. CAPS (Center of Academic Publishing Service), Yogyakarta.

Sutojo, S. 1995. Studi Kelayakan Proyek. PT Pustaka Binaman Pressindo, Jakarta.

Wilczenski, F. L. 1992. Measuring attitudes toward inclusive education. Psychology in the Schools, 29(4), pp.306-312. 